\title{
SUPPly Chain MANAGEMENT: An EMPIRICAL STUdy OF ITS IMPACT ON PERFORMANCE
}

\author{
Keah-Choon Tan \\ College of Business \\ Department of Management \\ University of Nevada, Las Vegas \\ Las Vegas, NV 89154-6009 \\ Tel: (702) 895-3873 \\ Fax: (702) 895-4370 \\ kctan@nevada.edu \\ Vijay R. Kannan* \\ James Madison University \\ Harrisonburg, VA 22807 \\ Tel: (540) 5683053 \\ Fax: (540) 5683273 \\ kannanvr@jmu.edu \\ Robert B. Handfield \\ The Eli Broad Graduate School of Management \\ Department of Marketing \& Logistics \\ Michigan State University \\ East Lansing, MI 48824-1122 \\ Tel: (517) 432-3514 \\ Fax: (517) 432-1112 \\ handfiel@pilot.msu.edu \\ Soumen Ghosh \\ DuPree School of Management \\ Georgia Institute of Technology \\ Atlanta, GA 30332-0520 \\ Tel: (404) 894-4927 \\ Fax: (404) 894-6030 \\ soumen.ghosh@mgt.gatech.edu
}

December 8, 1998

* Corresponding author 


\section{ABSTRACT

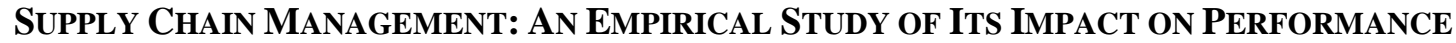

Total quality management, supply base management, customer driven corporate policy, and other elements of supply chain management are frequently cited as strategic options to achieve competitive success in the 1990's. However, attempts by companies to implement these options have not been universally successful and have in many cases failed to yield the desired results. This study presents details of a survey carried out to determine whether particular quality management, supply base management, and customer relations practices can impact corporate performance. In addition it examines the impact analyzing the competitive environment has on performance. Regression models identify several factors that directly and positively impact corporate performance. These include the extent to which companies analyze the strategies of competitors and determine future customer requirements, and the commitment they have to evaluating performance throughout the supply chain.

Key Words: Supply Chain Management, Total Quality Management, Customer Service.

This research was supported by a grant from the Center for International Business Education and Research (CIBER) at Michigan State University. 


\section{Introduction}

In the 1980's, intense global competition forced business organizations to offer high quality products at low cost while simultaneously increasing design flexibility. Producers embraced the principles of Just-in-Time and Total Quality Management (TQM) as they sought to enhance competitiveness. Companies implemented practices including benchmarking, process control techniques, and training and involvement programs as they recognized the importance of building quality into products (Ebrahimpour, 1985, Modarress and Ansari, 1989, Schroeder et al., 1992). Senior management leadership on quality related matters, strategic quality planning, and evaluation of information on quality also became part of the management agenda (Benson et al., 1991, Saraph et al., 1989).

As competition in the 1990's intensified further, so did the challenges associated with getting a product or service to the right place at the right time at the lowest delivered total cost. Manufacturing organizations began to realize the potential benefits and importance of strategic and cooperative buyersupplier relationships. Organizations began to involve strategic suppliers in resource management decisions (Morgan and Monczka, 1996). Instead of relying on tools such as acceptance sampling to establish the quality of incoming materials and component parts, manufacturers purchased from a more limited number of qualified or certified suppliers (Inman and Hubler, 1992). Many producers embraced the concept of supply base management, hoping to reduce costs by cutting inventory and improving efficiency throughout the supply chain (Watts and Hahn, 1993, Krause, 1997). In addition, organizations placed more emphasis on customer driven corporate policies that sought to simultaneously pursue objectives of customer satisfaction, quality and productivity improvement, and cost reduction.

The simultaneous integration of customer requirements, internal processes, and upstream supplier performance is commonly referred to as Supply Chain Management (SCM). While SCM has become popular, there are in practice few examples of truly integrated supply chains (Handfield and Nichols, 1998). Although the popular press is replete with reports of firms that developed strategic supplier-buyer partnerships, outsourced non-core competencies, and adopted strategic customer relations practices, few companies have succeeded simultaneously on all these fronts. Similarly, many TQM initiatives have 
failed to achieve their desired results despite tremendous resources having been expended on them (Hiam, 1993).

Given the failure of so many TQM and SCM efforts to yield the desired improvements in performance, the question remains whether specific TQM and SCM practices can positively impact corporate performance. It is also unclear how competition and management's response to it impacts performance. This study describes a research effort that addresses these questions. The study has four underlying objectives. The first is to identify how specifically a firm's competitive environment and management's response to it affects performance. The three remaining objectives relate to the question of whether specific TQM and SCM practices affect performance. Specifically, the study seeks to identify how a firm's TQM, supply base management, and customer relations practices affect performance.

\section{Research Constructs}

\section{Competitive Environment}

In the 1950's and 1960's, the primary operations strategy of most manufacturers was one of unit cost reduction. This was accomplished using mass production methods, with little attention being paid to product or process flexibility. New product development was slow and relied exclusively on in-house technology and capacity. Increasing competition brought with it the advent of modern management philosophies such as TQM, supply base management and customer driven corporate strategy. These philosophies have brought about a shift in supplier-buyer relationships. Relationships that were once adversarial are now being developed as strategic alliances (Monczka et al., 1998). Manufacturers are increasingly tapping into suppliers' technologies and expertise in product design and development, a concept commonly known as early supplier involvement (Ragatz et al., 1997). Increasing numbers of companies also are adopting TQM programs (Hiam, 1993) or developing a more customer oriented focus to improve their competitive position.

While it can be expected that the overall level of competition in a firm's primary industry, will, by providing the impetus for a critical evaluation of business practices, affect its performance, there is 
little empirical research linking the competitive environment to a firm's performance. For the purposes of this research, the competitiveness of the environment is therefore operationalized in terms of the intensity of competition. Six indicators of competitive intensity were developed (Appendix I, part I). These include management's perceptions of the aggressiveness of competitors, the time and effort taken by management to analyze and respond to the strategies and actions of competitors, and management's perceptions of overall industry competitiveness.

\section{Total Quality Management Practices}

Over the past ten years, TQM has become a pervasive element of business strategy, and is considered by business executives to be one of their main strategic issues (Malhotra et al., 1994). In the last decade alone, between seventy-five and eighty percent of large companies have adopted TQM programs (Hiam, 1993). However, while TQM efforts at companies such as Harley-Davidson and Xerox have resulted in improved competitiveness, similar results in other organizations have remained elusive (Grant et al., 1994). Although the literature on quality management is replete with approaches to managing quality, it contains little evidence of well defined linkages between practice and outcome. The result has been that companies have implemented quality initiatives in a piecemeal manner or without understanding their impact (Schaffer and Thomson 1992, Cole 1993). Only recently have efforts been made to develop a theory of quality management or to empirically identify relationships between quality practice and organizational performance (Anderson et al., 1994, 1995, Flynn et al., 1995, Ahire et al., 1996).

Recent evidence indicates that leading edge companies are shifting their quality emphasis from inspection to designing quality into products, accompanying this with process control and process improvement efforts (Greene, 1993). These initiatives, particularly when implemented concurrently with managing the supply base, were cited as strategic practices to achieve competitive advantage. Other practices associated with quality improvement mirror those embodied in the evaluation criteria for awards such as the Baldrige and Deming awards (Anderson et al., 1994, 1995, Black and Porter, 1996). These 
include strategic quality planning and senior management leadership. However, despite the shift toward designing quality into products, some quality professionals and academicians argue that there is still a need for inspection (Sower et al., 1993).

To operationalize TQM practice, thirty-eight practices were identified ranging from the strategic management of quality to the use of specific tools and practices of quality management (Appendix I, part II). These include the commitment of top management to quality improvement, the training of senior managers, supervisors and hourly employees in quality methods, the use of benchmarking, and an emphasis on quality in dealing with customers and suppliers.

\section{Supply Base Management Practices}

In the face of a competitive global market, organizations have downsized, focused on core competencies, and attempted to achieve competitive advantage by more effectively managing purchasing activities and relationships with suppliers. Supply base management refers to how firms utilize their suppliers' processes, technologies, and capabilities to enhance competitive advantage (Farley, 1997), and how the manufacturing, logistics, materials, distribution and transportation functions are coordinated within organizations (Lee and Billington 1992). Many firms have reduced their supply base so they can more effectively manage relationships with strategic suppliers (Tully, 1995). Buying firms are developing cooperative, mutually beneficial relationships with suppliers and viewing suppliers as virtual extensions of their firm (Mason, 1996, Copacino, 1996). In doing so, they have significantly increased their reliance on suppliers.

A result of increasing reliance on suppliers has been that shortcomings in supplier performance and/or competency may present buying firms with problems such as missed shipping dates and inferior quality levels. For other companies however, superior supplier performance or capability may lead to superior quality and/or rapid integration of the latest technological breakthroughs into the buying firm's own products through early supplier involvement (Ragatz et al., 1997). Suppliers may also participate earlier in the product design process to render more cost-effective design choices, develop alternative 
conceptual solutions, select the best components and technologies, and help in design assessment (Monczka et al., 1994, Burt and Soukup, 1985). Emphasizing internal competencies requires greater reliance on external suppliers to support non-core requirements, particularly in design and engineering support (Prahalad and Hamel, 1990). Firms may thus find that they have replaced the need for one set of competencies with another, that of effectively managing relationships with suppliers.

Companies encountering problems due to increased reliance on suppliers use a variety of approaches to address the problems. They may reverse their downsizing emphasis and bring outsourced products and services back in-house, secure alternative sources of supply, or work with existing suppliers to increase their performance and capabilities (Watts and Hahn, 1993). Supplier development efforts vary in terms of the effort expended by the buying firm and in the variety of tools used. However, a recent study found that firms often use supplier evaluation or performance measurement to identify specific supplier deficiencies and to develop plans to address them (Krause, 1997). Such efforts may involve the measurement of suppliers' delivery, quality, and cost performance, site visits, certification of suppliers' products and processes, and the setting of performance goals.

For the purpose of this study, ten practices used to effectively manage the supply base and increase supplier performance were identified (Appendix I, part III). These include the use of quality assurance programs for monitoring supplier's processes and products, the use of site visits, and the sharing of information with suppliers.

\section{Customer Relations Practices}

A company's customer relations practices can affect its success in managing the supply base as well as its performance (Scott and Westbrook, 1991, Ellram, 1991, Turner, 1993). A key element of successful supply base management involves downstream integration of customers as well as the management of upstream suppliers. Each entity in the supply chain is a supplier as well as a customer. When a customer driven corporate vision is implemented simultaneously with effective TQM and supply base management practices, it can produce a competitive edge in a number of different ways. These 
include increases in productivity, reductions in inventory and cycle time, increased customer satisfaction, market share and profits. However, there is little empirical evidence in the literature linking customer relations practices and performance to support the conceptual foundation of customer driven corporate policy.

To operationalize customer relation practices, seven elements of customer service were identified (Appendix I, part IV). These include the evaluation of customer complaints and the measurement of customer satisfaction. A company's performance on these dimensions is an indicator of whether it is aware of the importance of customer satisfaction and of the company's dual roles as buyer and supplier in the value chain.

\section{Performance Measures}

Economists disagree about the use of accounting data to measure firm performance because it ignores opportunity costs and the time value of money (Chen and Lee, 1995). Business performance, the argument goes, should be measured by financial data, such as the internal rate of return (IRR). Financial data provides a measurement of a firm's performance via the market's valuation of the firm's securities. However, since future cash flows of the business entity cannot be observed, measures of business performance are typically based on accounting data such as return on investment (ROI) or return on assets (ROA).

Jahera and Lloyd (1992) observed that ROI was a valid performance measure for midsize firms. However, the validity of ROI as a performance measure has been challenged (Tobin and Brainard, 1968). A firm's financial leverage can affect its ROI to such a degree that it renders comparisons between firms meaningless. ROI also ignores opportunity costs and the time value of investments. An alternate measure of performance, Tobin's $q$ ratio, evaluates the ratio of the market value of a firm to the replacement cost of its assets (Tobin, 1969). However, the prospect of obtaining accurate measures of each firm's market value and the replacement cost of its assets to calculate Tobin's $q$ was deemed impractical for this research. 
Given the lack of consensus regarding a valid cross-industry measure of corporate performance, performance in this study was operationalized by senior management's perceptions of a firm's performance in comparison to that of major competitors (Tan et al., 1998). Nine dimensions of performance were considered including market share, return on assets (ROA), and overall competitive position (Appendix I, part V) ${ }^{1}$.

\section{Research Hypotheses and Survey Methodology}

The objective of this research is to examine the linkages between a firm's competitive environment, TQM, supply base management, and customer relation practices, and firm performance. This objective is driven by the notion that although firms have reengineered their internal operations to achieve higher quality levels, they have also become more dependent on their suppliers. As noted earlier, firms that have out-sourced non-core activities have realized they must now effectively manage the performance and capabilities of their suppliers of outsourced products and services. It can therefore be surmised that firms reporting the highest levels of financial and operational performance will be emphasizing not only internal quality initiatives, but also initiatives relating to the management of all elements of their supply chain including customers and suppliers, and the quality of delivered products. To test this proposition, the following hypotheses are proposed:

$\mathrm{H}_{1}$ : A firm's competitive environment and management's responsiveness to it affects its performance.

$\mathrm{H}_{2}$ : The use of TQM tools and practices positively affects performance.

$\mathrm{H}_{3}$ : Effective management of the supply base positively affects performance

$\mathrm{H}_{4}$ : A customer relations focus is positively related to high levels of performance.

\footnotetext{
${ }^{1}$ Performance measures were validated by comparing performance for a subset of firms to actual financial performance obtained from the Dun and Bradstreet database. Correlations were all statistically significant, providing support for the use of managers' perceptual measures as a proxy for actual performance.
} 
To obtain data to test the hypotheses, a survey instrument was designed based on the constructs described earlier. Respondents were asked to indicate the performance of their firm compared to that of major industry competitors, the level of competition in their firm's primary industry, the extent to which they used the quality and supply base management practices of interest, and their ability to monitor customer relationships (Appendix I). Questions were designed using a seven point Likert scale. In addition, several questions that sought general classification and demographic information on the company were posed. The survey instrument was pre-tested at meetings with quality managers/directors at ten firms in the United States and Europe. As a result of these interviews, the questionnaire was revised to improve clarity and content validity.

The survey was sent to 1,469 individuals identified from an American Society of Quality Control list of 3,000 quality directors and vice presidents. The firms represented by these individuals operated in a broad range of industries including the automotive, chemical, computer, construction, consumer products, defense, electronics, industrial products, medical device, packaging, pharmaceutical, paperboard, semiconductor, and telecommunications industries. Two mailings and one follow-up reminder resulted in a response rate of $21.3 \%$ (313 surveys returned).

\section{Preliminary Results}

\section{Sample Demographics}

Companies responding to the survey employed between 12 and 256,000 people with a mean of 5,228. Twenty two percent of the companies had fewer than 100 employees while another fifteen percent employed between 101 and 200 employees. Approximately nine percent of the companies employed more than 8,000 employees. Annual sales of the companies (1993) ranged from $\$ 1$ million to $\$ 65$ billion with a mean of approximately $\$ 900$ million. Sales in the United States and Canada accounted for $82 \%$ of the total, the remainder distributed throughout Western Europe (7\%), Japan and the Pacific Basin (4\%), Mexico and Latin America (3\%), and 2\% each in Southeast Asia and Central and Eastern Europe. When asked to indicate the level of competition they faced from competitors globally, respondents indicated that 
their firms faced the greatest competition in the United States and Canada followed by Western Europe and Japan and the Pacific Basin.

\section{Competitive Environment, Supply Chain Management Practices, and Performance}

Prior to analyzing responses to the five item scales of primary importance to the study (competitive environment, total quality management practices, supply base management practices, customer relations practices, and performance measures), Cronbach's $\alpha$ (Cronbach, 1951) was used to assess the reliability of each scale. Values of $\alpha$ in excess of 0.7 (Nunnally, 1988) indicate that all five scales can be considered to be reliable (Table 1).

Bonferroni multiple comparisons $(\alpha=0.05)$ showed that respondents considered the number of competencies required to survive $(\mu=5.89)$ to be the strongest indicator of industry competitiveness followed by the overall competitiveness of the industry $(\mu=5.84)$. The amount of time spent analyzing major competitors' strategies and actions $(\mu=4.30)$ was considered to be the weakest indicator of competitiveness. The most commonly used TQM practices are the development of procedures for monitoring key indicators of plant performance $(\mu=5.09)$ and top management emphasizing health and safety in quality policy $(\mu=5.05)$. These are followed by coordinating quality and other departments $(\mu=$ 5.03). The least commonly used TQM practice is the use of training in advanced statistical techniques $(\mu$ $=2.84)$.

A variety of supply base management practices are used by the firms which responded to the survey. These firms actively take advantage of their suppliers technical support and test capabilities $(\mu=$ 4.93). This finding supports the notion that manufacturers are integrating their suppliers' knowledge and capability into new product and process design. Decentralized purchasing of materials $(\mu=4.66)$ and allowing individual plants to source low volume, low cost materials $(\mu=4.66)$ are also widely practiced. The least commonly used practice is the use of commodity management teams to set supplier performance goals $(\mu=3.21)$. With regard to customer relations, firms rate themselves most highly on 
their ability to evaluate formal and informal complaints $(\mu=5.37)$. This is followed as a group by their ability to follow-up with customers for quality/service feedback $(\mu=5.10)$, their enhancement of customers' ability to seek assistance $(\mu=5.06)$, and their determination of key factors for building and maintaining customer relationships $(\mu=5.02)$. Respondents were least confident of their abilities in the areas of interaction with customers to set reliability, responsiveness and other standards $(\mu=4.68)$ and in the measurement and evaluation of customer satisfaction factors $(\mu=4.45)$.

Respondents evaluated their firms most highly on overall product quality $(\mu=5.59)$, followed by customer service level $(\mu=5.36)$ and overall competitive position $(\mu=5.27)$. Relative areas of concern were average annual sales growth $(\mu=4.94)$, average annual market share growth $(\mu=4.86)$, return on assets $(\mu=4.81)$, and average annual growth in return on assets $(\mu=4.68)$.

\section{Statistical Analysis}

Factor Analysis

For each of the item scales, factor analysis was used to reduce the total number of items to a smaller number of underlying factors. Principal Components Analysis was used to extract factors (eigen values $>1$ ). Varimax rotation was used to facilitate interpretation of the factor matrix. The Bartlett Test of Sphericity and the Kaiser-Meyer-Olkin measure of sampling adequacy were used to validate the use of factor analysis. Factor analyses of the competitive environment and customer relations practices scales indicated the existence of six and seven factors respectively. This suggests that the two scales should not be reduced by factor analysis. The six competitive environment items and seven customer relations practices were therefore treated as independent factors, to be referred to as $\mathrm{CE}_{1}-\mathrm{CE}_{6}$ and $\mathrm{CR}_{1}-\mathrm{CR}_{7}$ respectively.

The thirty-seven TQM practices were reduced to seven underlying factors referred to as $\mathrm{TQM}_{1}-$ $\mathrm{TQM}_{7}$ (Table 2). These factors reflect top management involvement and commitment to quality programs, and both strategic and operational practices that reflect an orientation towards quality. The nine 
supply base management practices were reduced to three underlying factors referred to as $\mathrm{SBM}_{1}-\mathrm{SBM}_{3}$ (Table 3) addressing the evaluation and involvement of suppliers and the decentralization of purchasing. The eight measures of performance were reduced to two factors referred to as $\mathrm{PM}_{1}$ and $\mathrm{PM}_{2}$ (Table 4). These include a measure of growth and return on assets, and a measure overall performance and market share.

\section{Regression Analysis}

Stepwise multiple linear regression was used to develop models relating the two measures of performance to the twenty-three independent variables (Tables 5 and 6). Significance levels of $\alpha=0.05$ and 0.10 were used for entering and exiting variables respectively. The Durbin-Watson was used to verify that residuals were independent and normal probability plots were used to verify that residuals were normally distributed.

\section{Discussion}

One competitive environment variable, $\mathrm{CE}_{4}$, was significant in both regression models. This provides evidence to support the assertion that competitiveness can be compromised if management fails to adequately analyze the competitive environment. The variable's negative correlation with growth and ROA does however suggest that devoting resources to analysis of competitors' strategies and actions can compromise growth and returns on asset. Such an outcome could occur if the analysis causes an organization to act in a reactive manner in response to a competitor's strategy, and diverge from an otherwise preferred strategy. The models also suggest that it is the strategies of competitors that impact competitiveness rather than specific actions they might carry out or their positioning in terms of aggressiveness or number of competitive strengths. Not surprisingly, overall industry competitiveness correlates positively with overall performance, further supporting acceptance of hypothesis $\mathrm{H}_{1}$.

The impact of quality on performance has been extensively discussed in the literature. The current analysis however shows that the impact quality has on performance depends on the dimension of 
performance being measured. Only one TQM factor, $\mathrm{TQM}_{2}$, has a positive impact on growth and ROA. This reflects the fact that in a competitive environment, growth in sales, market share, or return an assets requires an organization to benchmark performance and implement mechanisms that allow it to respond to competitive pressures. However, when one examines overall performance, three factors, $\mathrm{TQM}_{1}, \mathrm{TQM}_{4}$, and $\mathrm{TQM}_{6}$ are significant, providing further support for hypothesis $\mathrm{H}_{2}$. The significance of these three factors illustrates the importance of having a strategic orientation towards quality rather than using piecemeal attempts to achieve quality. It also suggests the merits of a quality strategy that does not place undue attention on short-term performance.

The positive correlation between factor $\mathrm{CR}_{1}$ and the growth and ROA measure of performance is significant for two reasons. First, it highlights the need to work with customers and identify their needs and expectations. Second, combined with the significance of using performance data in quality management, it demonstrates the importance of managing performance aggressively. In an intensely competitive environment, maintaining and improving one's competitive position requires efforts to better anticipate market needs and to identify and eliminate potential weaknesses in performance. The importance of a customer-oriented strategy is further illustrated by the fact that enhancing customers' ability to seek assistance has the greatest impact on overall performance. This analysis provides support for hypothesis $\mathrm{H}_{3}$.

Managing the supply base has a significant impact on growth but not on overall performance. Evaluating suppliers and involving them in the decision making process are both positively related to growth and ROA. Supplier involvement has the greatest impact on growth and ROA of any of the six factors included in the regression model. The significance of managing the supply base is consistent with recent evidence that suggests that managing the supply chain is crucial to enhancing performance. As organizations downsize and outsource key inputs, maintaining control over the quality of inputs, lead times, and delivery reliability requires closer coordination with and involvement of suppliers throughout the production process. It also increases the need for organizations to ensure the quality of their suppliers. 
This research indicates that effective management of certain aspects of supply base activities contributes to higher level of performance, providing support for hypothesis $\mathrm{H}_{4}$.

\section{Conclusion}

Improving product and process quality have been well established as ways by which organizations can respond to increased global competition. Now however, the challenges facing organizations go beyond improving quality. Organizations are increasingly faced with the reality that they cannot exist in isolation but are one piece of a complex chain of business activity. The results of this study support this notion and confirm that all three major components of a supply chain, suppliers, manufacturers, and customers, must be effectively integrated in order to achieve financial and growth objectives. Moreover, the results indicate well defined linkages between specific practices and performance. Successful management of the supply chain is the key to the long-term success of an organization. This cannot occur however if organizations implement business practices in an arbitrary, uncoordinated manner, or if they direct scarce financial resources to initiatives that are unlikely to yield positive outcomes.

The results also highlight the fact that supply chain management initiatives alone cannot improve profitability and market share. With product life cycles shrinking, firms must unceasingly pursue new markets, new technologies, and improve cost and delivery performance. Supply chain management provides a framework within which to implement a well conceived market strategy, but it cannot undo the effects of a poorly conceived one. It is therefore imperative for managers to ensure their quality and procurement implementation strategies, tactics, and measurements are correctly aligned with strategies in the areas of finance, operations, marketing, new product development, and sales.

Future research is needed to extend the findings of this study. The study has addressed the practices of organizations only one tier upstream and downstream. In the future, truly integrated supply chains may consist of multiple organizations in a chain working together to bring the latest technological innovations and products to customers at the lowest cost in the shortest time. There is a need to 
understand how future strategies will unfold and how organizational strategies will merge given different competitive objectives. An additional question is how will companies share financial rewards.

\section{REFERENCES}

Ahire, S.L., Golhar, D.Y., and Waller, M.A. (1996), "Development and validation of TQM implementation constructs", Decision Sciences, Vol. 27 No. 1, pp. 23-56.

Anderson, J.C., Rungtusanatham, M., and Schroeder, R.G. (1994), "A theory of quality management underlying the Deming method”, Academy of Management Review, Vol. 19 No. 3, pp. 472-509.

Anderson, J.C., Rungtusanatham, M., Schroeder, R.G., and Devaraj, S. (1995), A path analytic model of a theory of quality management underlying the Deming management method: Preliminary empirical findings", Decision Sciences, Vol. 26 No. 5, pp. 637-658.

Benson, P.G., Saraph, J.V., and Schroeder, R.G. (1991), "The effects of organizational context on quality: An empirical investigation", Management Science, Vol. 37 No. 9, pp. 1107-1124.

Black, S.A., and Porter, L.J. (1996), "Identification of the critical factors of TQM.”, Decision Sciences, Vol. 27 No. 1, pp. 1-22.

Burt, D. N. and Soukup, W. R. (1985), "Purchasing's role in new product development", Harvard Business Review, Sept-Oct, pp. 90-97.

Chen, K.C.W., and Lee, C.W.J. (1995), “Accounting measures of business performance and Tobin's q theory", Journal of Accounting, Auditing \& Finance, Vol. 10 No. 3, pp. 587-609.

Cole, R.E. (1993), "Introduction to the special issue on total quality management", California Management Review, Vol. 35, pp. 7-11.

Copacino, W.C. (1996), “Seven supply-chain principles”, Traffic Management, Vol. 35 No. 1, pp. 60.

Cronbach, L.J. (1951), "Coefficient alpha and the internal structure of tests", Psychometrika, Vol. 16, pp. 297-334.

Ebrahimpour, M.. (1985), "An examination of quality management in Japan: Implications for management in the United States", Journal of Operations Management, Vol. 5 No. 4, pp. 519-431.

Ellram, L.M.. (1991), "Supply chain management: The industrial organization perspective", International Journal of Physical Distribution and Logistics Management, Vol. 21 No. 1, pp. 13-22.

Farley, G.A. (1997), "Discovering supply chain management: A roundtable discussion", APICS - The Performance Advantage, Vol. 7 No. 1, pp. 38-39.

Flynn, B.B., Schroeder, R.G., and Sakakibara, S. (1995), "The impact of quality management practices on performance and competitive advantage”, Decision Sciences, Vol. 26 No. 5, pp. 659-692.

Grant, R.M., Shani, R., and Krishnan, R. (1994), “TQM's challenge to management theory and practice”, Sloan Management Review, Vol. 35 No. 2, pp. 25-35.

Greene, R. (1993), Global Quality: A synthesis of the world's best management models, ASQC Press, Milwaukee, WI.

Handfield, R.B., and Nichols, E.L. Jr. (1998), An Introduction to Supply Chain Management, Prentice Hall, Upper Saddle River, NJ. 
Hiam, A. (1993), Does quality work? A review of relevant studies, The Conference Board, New York, NY.

Inman, R.A., and Hubler, J.H. (1992), "Certify the process, not just the product", Production and Inventory Management Journal, Vol. 33 No. 4, pp. 11-14.

Jahera, J. S., and Lloyd, W.P. (1992), "Additional evidence on the validity of ROI as a measure of business performance", The Mid-Atlantic Journal of Business, pp. 105-112.

Krause, D.R. (1997), "Supplier development: Current practices and outcomes," International Journal of Purchasing and Materials Management, Vol. 33 No. 2, pp. 12-19.

Lee, H.L., and Billington, C. (1992), "Managing supply chain inventory: Pitfalls and opportunities", Sloan Management Review, Vol. 33 No. 3, pp. 65-73.

Malhotra, M.D., Steele, D.C., and Grover, V., (1994), "Important strategic and tactical manufacturing issues in the 1990's”, Decision Sciences, Vol. 25 No. 1, pp. 189-214.

Mason, T. (1996), “Getting your suppliers on the team”, Logistics Focus, Vol. 4 No. 1, pp. 10-12.

Modarress, B., and Ansari, A. (1989), "Quality control techniques in U.S. firms: A survey", Production and Inventory Management Journal, Vol. 30 No. 2, pp. 58-62.

Monczka, R. M., Trent, R. J., and Callahan, T. J. (1994), "Supply base strategies to maximize supplier performance", International Journal of Physical Distribution and Logistics, Vol. 24 No. 1, pp. 42-54.

Monczka, R., Peterson, K., Handfield, R., and Ragatz, G. (1998), "Determinants of successful vs. nonsuccessful strategic supplier alliances”, Decision Sciences, Vol. 29, No. 3, pp. 553-577.

Morgan, J., and Monczka, R.M. (1996), "Supplier integration: A new level of supply chain management", Purchasing, Vol. 120 No. 1, pp. 110-113.

Nunnally, J.C. (1988), Psychometric theory. McGraw Hill, Englewood Cliffs, NJ.

Prahalad, C. K., and Hamel, G. (1990), "The core competence of the corporation", Harvard Business Review, Vol. 68 No. 3, pp. 79-91.

Ragatz, G., Handfield, R., and Scannell, T. (1997), "Success factors for integrating suppliers into new product development”, Journal of Product Innovation Management, Vol. 14, pp. 190-202.

Saraph, J.V., Benson, P.G., and Schroeder, R.G. (1989), "An instrument for measuring the critical factors of quality management”, Decision Sciences, Vol. 20 No. 4, pp. 810-829.

Schaffer, R., and Thomson, H. (1992), "Successful change programs begin with results", Harvard Business Review, Vol. 70, pp. 80-89.

Schroeder, R.G., Sakakibara, S., Flynn, E.J., and Flynn, B.B. (1992), "Japanese plants in U.S.: How good are they?", Business Horizons, Vol. 335 No. 4, pp. 66-72.

Scott, C., and Westbrook, R. (1991), "New strategic tools for supply chain management", International Journal of Physical Distribution and Logistics, Vol. 21 No. 1, pp. 23-33.

Tan, K.C., Handfield, R.B., and Krause, D.R. (1998), "Enhancing firm's performance through quality and supply base management: An empirical study", International Journal of Production Research, Vol. 36 No. 10, pp. 2813-2837.

Tobin, J. (1969), “A general equilibrium approach to monetary theory", Journal of Money, Credit and Banking, Vol. 1, pp. 15-29. 
Tobin, J., and Brainard, W. (1968), "Pitfalls in financial model building", American Economic Review, Vol. 58, pp. 99-122.

Tully, S. (1995), “Purchasing's new muscle”, Fortune, Vol. 20, pp. 76.

Turner, J.R.. (1993), “Integrated supply chain management: What's wrong with this picture?", Industrial Engineering, Vol. 25 No. 12, pp. 52-55.

Watts, C.A. and Hahn, C. K. (1993), "Supplier development programs: An empirical analysis", International Journal of Purchasing and Materials Management, Vol. 29 No. 2, pp. 11-17. 
Table 1: Reliability Analysis

\begin{tabular}{|c|c|c|}
\hline Scale & $\alpha$ & Notes \\
\hline Competitive Environment & 0.803 & \\
\hline Total Quality Management Practices & 0.956 & $\begin{array}{l}\text { Item } 35 \text { correlated negatively with other items in the scale. } \\
\text { When it was omitted, a value of } \alpha=0.961 \text { was obtained. Item } \\
35 \text { was omitted from subsequent analysis }\end{array}$ \\
\hline Supply Base Management Practices & 0.736 & $\begin{array}{l}\text { Only } 5.1 \% \text { of variation can be explained by item } 8 \text {. When it } \\
\text { was omitted, a value of } \alpha=0.763 \text { was obtained. Item } 8 \text { was } \\
\text { omitted from subsequent analysis }\end{array}$ \\
\hline Customer Relations Practices & 0.880 & \\
\hline Performance Measures & 0.809 & $\begin{array}{l}\text { Item } 6 \text { correlated weakly with other items in the scale. When it } \\
\text { was omitted, a value of } \alpha=0.833 \text { was obtained. Item } 6 \text { was } \\
\text { omitted from subsequent analysis }\end{array}$ \\
\hline
\end{tabular}


Table 2: Rotated Factor Matrix - TQM Practices

\begin{tabular}{|c|c|c|c|c|c|c|c|}
\hline TQM1 & TQM2 & TQM3 & $\mathrm{TQM}_{4}$ & TQM5 & TQM6 & TQM7 $_{7}$ & TQM Practices \\
\hline 0.6931 & 0.1718 & 0.1662 & 0.2660 & 0.1916 & 0.1922 & 0.1363 & 31. Top management provides resources to carry out quality improvement \\
\hline 0.6871 & 0.2575 & 0.2622 & 0.1774 & 0.0560 & 0.2751 & 0.0233 & 29. Top management emphasizes quality through well-defined quality policy \\
\hline 0.6848 & 0.3034 & 0.2014 & 0.1609 & 0.1130 & 0.3359 & 0.1010 & 28. Top management clearly communicates quality goals \\
\hline 0.6832 & 0.3213 & 0.0318 & 0.2233 & 0.1397 & 0.2295 & 0.0520 & 30. Top management focuses on customer quality needs in setting strategy \\
\hline 0.6480 & 0.2460 & 0.2149 & 0.0598 & 0.2612 & 0.2103 & 0.1196 & 33. Management's efforts to reward quality improvements \\
\hline 0.6138 & 0.0112 & 0.0799 & 0.0472 & 0.3758 & 0.1233 & 0.1833 & 36.Responsiveness of employees in making suggestions for quality improvement \\
\hline 0.6075 & 0.2143 & 0.1288 & 0.1732 & 0.1388 & 0.0987 & 0.3048 & 10. Company environment is conducive to employee well-being and growth \\
\hline 0.5987 & 0.4357 & 0.1712 & 0.1649 & 0.2010 & 0.0627 & 0.1192 & 12. Employees throughout organization are evaluated on quality results \\
\hline 0.5736 & 0.4433 & 0.1011 & 0.2213 & 0.1198 & 0.1274 & 0.0670 & 11. Divisional top managers are evaluated based on quality performance \\
\hline 0.5302 & 0.1293 & 0.1649 & 0.1700 & 0.2390 & 0.1404 & 0.3632 & 18. Emphasis on quality instead of price in supplier selection \\
\hline 0.4394 & 0.3622 & 0.0016 & 0.2317 & 0.3120 & -0.0567 & 0.3172 & 13. Emphasis on quality in design process vis-à-vis cost, schedules \\
\hline 0.2112 & 0.7398 & 0.1544 & -0.0206 & 0.1402 & 0.0503 & 0.1290 & 14. Procedures for monitoring key indicators of competitor performance \\
\hline 0.3682 & 0.6572 & 0.1096 & 0.1756 & 0.0595 & 0.1910 & 0.1069 & 15. Procedures for monitoring key indicators of customer satisfaction \\
\hline 0.1378 & 0.5874 & 0.2468 & 0.1865 & 0.0986 & 0.1569 & -0.1055 & 8. Collection of after sales quality data \\
\hline 0.2021 & 0.5318 & 0.3703 & -0.0034 & 0.1152 & 0.1112 & 0.0582 & 1. Use of benchmark data to improve quality practices \\
\hline 0.2331 & 0.5110 & 0.1157 & 0.2775 & 0.2268 & 0.1265 & 0.1512 & 16. Procedures for monitoring key indicators of plant/company performance \\
\hline 0.2304 & 0.4903 & 0.0548 & 0.3186 & 0.2032 & 0.0918 & 0.3314 & 9. Coordination among appropriate departments in product/service development \\
\hline 0.1646 & 0.3569 & 0.1726 & 0.2119 & 0.2986 & 0.3380 & 0.3532 & 23. Formalization of interfaces among different functional departments \\
\hline 0.0667 & 0.2263 & 0.7601 & 0.1347 & 0.2541 & 0.1021 & 0.1847 & 5. Training in basic statistical techniques \\
\hline 0.4668 & 0.1310 & 0.6804 & 0.1926 & 0.0840 & 0.0420 & 0.0484 & 3. Training in quality awareness for hourly employees \\
\hline-0.0419 & 0.2662 & 0.6529 & 0.0983 & 0.1980 & 0.1564 & 0.3149 & 6. Training in advanced statistical techniques \\
\hline 0.4831 & 0.1818 & 0.6397 & 0.1497 & 0.0135 & 0.0971 & 0.0495 & 4. Training in quality awareness for managers/supervisors \\
\hline 0.2131 & 0.0852 & $\mathbf{0 . 5 3 1 3}$ & 0.4898 & 0.0827 & 0.0940 & 0.1128 & 34. Quality department active in providing specific training \\
\hline 0.1003 & -0.0010 & 0.0737 & 0.8198 & 0.1137 & 0.1304 & 0.0197 & 38. Visibility of the quality department \\
\hline 0.2761 & 0.2577 & 0.1686 & 0.6540 & 0.0407 & 0.0896 & 0.2222 & 17. Effectiveness of quality department in improving quality \\
\hline 0.2847 & 0.2932 & 0.2812 & 0.6093 & 0.0662 & 0.1486 & 0.1824 & 2. Coordination between quality and other departments \\
\hline 0.1871 & 0.2371 & 0.3489 & 0.4810 & 0.3806 & 0.1138 & -0.2589 & 7. Availability of quality data internal to organization \\
\hline 0.2461 & 0.1610 & 0.0963 & 0.0151 & 0.6486 & 0.0468 & 0.3692 & 24. Emphasis on manufacturability in product design \\
\hline 0.1540 & 0.1527 & 0.2140 & 0.1965 & 0.6323 & 0.2278 & 0.1785 & 25. Manufacturing facility used as a showroom for quality practices \\
\hline 0.3036 & 0.1805 & 0.1059 & 0.4623 & 0.5758 & 0.0538 & -0.0744 & 37. Timeliness of quality data internal to organization \\
\hline 0.3217 & 0.2292 & 0.4406 & 0.1981 & 0.5241 & 0.1391 & -0.1052 & 26. Quality data is displayed at work stations \\
\hline 0.3955 & 0.3524 & 0.1906 & -0.1281 & 0.4652 & 0.1799 & 0.0723 & 32. Inclusion of customer attributes in product design using QFD \\
\hline 0.2286 & 0.1256 & 0.0358 & 0.1401 & 0.1458 & 0.7984 & 0.1830 & 21. Top management's emphasis on health and safety in quality policy \\
\hline 0.3442 & 0.1513 & 0.2154 & 0.1199 & 0.1184 & 0.7522 & 0.0511 & 27. Top management's emphasis on environmental protection in quality policy \\
\hline 0.3553 & 0.3218 & 0.1528 & 0.1729 & 0.1060 & $\mathbf{0 . 5 0 8 5}$ & 0.1680 & 22. Human resources management affected by quality plans \\
\hline 0.2812 & 0.1300 & 0.2485 & 0.0280 & 0.1262 & 0.2143 & 0.6496 & 19. Utilization of cross functional teams \\
\hline 0.4257 & 0.0771 & 0.1994 & 0.1818 & 0.1055 & 0.1877 & 0.5105 & 20. Empowerment of employees on quality issues \\
\hline 15.6635 & 1.8925 & 1.5008 & 1.3404 & 1.2572 & 1.1636 & 1.0338 & Eigen value \\
\hline 42.3 & 5.1 & 4.1 & 3.6 & 3.4 & 3.1 & 2.8 & Percent of variation explained \\
\hline Note: & \multicolumn{4}{|c|}{$\begin{array}{l}\text { Factor TQM } \\
\text { Factor } \mathrm{TQM}_{3}: \text { Use of quality related training } \\
\text { Factor TQM } \mathrm{TQ}_{5}: \text { Use of operational quality practices } \\
\text { Factor TQM } \mathrm{T}_{7} \text { : Delegation of responsibility }\end{array}$} & \multicolumn{3}{|r|}{$\begin{array}{l}\text { Factor TQM } \\
\text { Factor } \mathrm{TQM}_{4} \text { : Involve of performance data in quality management } \\
\text { Factor TQMality department } \\
\text { : Social responsibility of management }\end{array}$} \\
\hline
\end{tabular}


Table 3: Rotated Factor Matrix - Supply Base Management (SBM) Practices

\begin{tabular}{cccl}
\hline \hline SBM$_{1}$ & SBM $_{2}$ & SBM $_{3}$ & \multicolumn{1}{c}{ SBM Practices } \\
\hline $\mathbf{0 . 8 9 8 0}$ & 0.0139 & 0.0156 & 5. Quality assurance program for supplier's processes \\
$\mathbf{0 . 7 8 1 8}$ & 0.0652 & 0.0992 & 4. Quality assurance program for supplier's products \\
$\mathbf{0 . 6 3 8 6}$ & 0.4245 & 0.0989 & 7. Manufacturing personnel visit supplier's facility regularly \\
$\mathbf{0 . 5 7 5 5}$ & 0.2930 & 0.0938 & 1. Commodity management teams set supplier performance targets \\
-0.0739 & $\mathbf{0 . 8 2 4 1}$ & 0.0912 & 10. Annual price negotiations for key input items \\
0.3331 & $\mathbf{0 . 6 0 3 5}$ & 0.0828 & 6. Use suppliers' technical support and test capabilities \\
0.4433 & $\mathbf{0 . 5 9 2 7}$ & -0.0245 & 9. Share confidential information with suppliers \\
0.1072 & 0.0589 & $\mathbf{0 . 8 8 6 9}$ & 2. Decentralized purchase orders and daily supply flows \\
0.0578 & 0.0796 & $\mathbf{0 . 8 8 4 3}$ & 3. Decentralized purchasing of low volume, low cost items \\
\hline 3.2219 & 1.4811 & 1.0690 & Eigen value \\
35.8 & 16.5 & 11.9 & Percent of variation explained \\
\hline \hline
\end{tabular}

Note: Factor $\mathrm{SBM}_{1}$ : Supplier Evaluation Factor $\mathrm{SBM}_{2}$ : Supplier Involvement

Factor $\mathrm{SBM}_{3}$ : Decentralization of Purchasing

Table 4: Rotated Factor Matrix - Performance Measures

\begin{tabular}{ccl}
\hline $\mathbf{P M}_{\mathbf{1}}$ & $\mathbf{P M}_{\mathbf{2}}$ & \multicolumn{1}{c}{ Performance Measures } \\
\hline $\mathbf{0 . 8 6 5 0}$ & 0.1124 & 4. Growth - Sales \\
$\mathbf{0 . 8 6 4 3}$ & 0.1378 & 5. Growth - ROA \\
$\mathbf{0 . 8 5 5 4}$ & 0.1396 & 3. Growth - Market Share \\
$\mathbf{0 . 6 7 3 5}$ & 0.3607 & 2. ROA \\
0.0009 & $\mathbf{0 . 8 2 5 1}$ & 8. Overall Product Quality \\
0.1022 & $\mathbf{0 . 7 4 6 1}$ & 7. Overall Customer Service \\
0.4719 & $\mathbf{0 . 6 7 7 7}$ & 9. Overall Competitive Position \\
0.2978 & $\mathbf{0 . 4 9 3 9}$ & 1. Market Share \\
\hline 3.7679 & 1.3564 & Eigen value \\
47.1 & 17.0 & Percent of variation explained \\
\hline \hline
\end{tabular}

Note: Factor $\mathrm{PM}_{1}$ : Growth and ROA

Factor $\mathrm{PM}_{2}$ : Overall Performance 
Table 5: Stepwise Multiple Regression Model for Perfomance Measure PM$_{1}$

\begin{tabular}{|c|c|c|c|c|c|}
\hline Analysis of Variance & $\mathrm{DF}$ & SS & MS & $\mathrm{F}$ & $\mathrm{p}$ \\
\hline Regression & 5 & 49.6432 & 9.9286 & 12.3792 & 0.0000 \\
\hline Residual & 257 & 206.1252 & 0.8020 & & \\
\hline \multicolumn{6}{|l|}{$\mathrm{R}^{2}=0.4406$} \\
\hline INDEPENDENT VARIABLES & Coeff. & Std Error & Beta & $\underline{\mathrm{p}}$ & \\
\hline$\overline{\mathrm{CE}_{4} \text { (Time spent analyzing competitors' strategies \& actions) }}$ & -0.1368 & 0.0426 & $-0 . \overline{1890}$ & 0.0015 & \\
\hline $\mathrm{CR}_{1}$ (Determine future customer expectations) & 0.1881 & 0.0454 & 0.2465 & 0.0000 & \\
\hline $\mathrm{SBM}_{1}$ (Supplier evaluation) & 0.1272 & 0.0593 & 0.1254 & 0.0330 & \\
\hline $\mathrm{SBM}_{2}$ (Supplier involvement) & 0.2104 & 0.0572 & 0.2151 & 0.0003 & \\
\hline $\mathrm{TQM}_{2}$ (Use of performance data in quality management) & 0.1250 & 0.0604 & 0.1276 & 0.0395 & \\
\hline Constant & -0.3078 & 0.2834 & & & \\
\hline
\end{tabular}

Table 6: Stepwise Multiple Regression Model for Perfomance Measure $\mathbf{P M}_{2}$

\begin{tabular}{|c|c|c|c|c|c|}
\hline Analysis of Variance & DF & SS & MS & $\mathrm{F}$ & $\mathrm{p}$ \\
\hline Regression & 6 & 63.7048 & 10.6175 & 14.8815 & 0.0000 \\
\hline Residual & 256 & 182.6483 & 0.7135 & & \\
\hline \multicolumn{6}{|l|}{$R^{2}=0.5085$} \\
\hline INDEPENDENT VARIABLES & Coeff. & $\underline{\text { Std Error }}$ & Beta & $\mathrm{p}$ & \\
\hline$\overline{\mathrm{CE}}_{4}$ (Time spent analyzing competitors' strategies \& actions) & $\overline{0.1249}$ & 0.0412 & $0 . \overline{1758}$ & 0.0027 & \\
\hline $\mathrm{CE}_{6}$ (Overall competitiveness of industry) & 0.1622 & 0.0556 & 0.1707 & 0.0038 & \\
\hline $\mathrm{CR}_{3}$ (Enhancement of customers' ability to seek assistance) & 0.2017 & 0.0494 & 0.2446 & 0.0001 & \\
\hline $\mathrm{TQM}_{1}$ (Management Commitment to Quality) & 0.1324 & 0.0550 & 0.1370 & 0.0167 & \\
\hline $\mathrm{TQM}_{4}$ (Involvement of Quality Department) & 0.1234 & 0.0555 & 0.1256 & 0.0271 & \\
\hline $\mathrm{TQM}_{6}$ (Social Responsibility of Management) & 0.1260 & 0.0544 & 0.1265 & 0.0213 & \\
\hline Constant & -2.4808 & 0.3786 & & & \\
\hline
\end{tabular}




\begin{abstract}
APPENDIX I

\section{Competitive Environment}

On a scale of $1=$ low to $7=$ high, indicate the overall level of competition in your firm's primary industry for each of the dimensions below:

1. The time, effort, resources and managerial attention required to keep up with competitors

2. Importance of potential competitor reaction or retaliation to decisions made in our firm

3. Number of competencies (i.e. things a firm must do well) required to survive in this industry

4. Amount of time spent analyzing major competitors' strategies and actions

5. Aggressiveness of our major competitors

6. Overall competitiveness of our industry
\end{abstract}

\title{
II. Total Quality Management Practices
}

On a scale of $1=$ very low to $7=$ very high, indicate the most appropriate response regarding your firm's practice of the following:

1. Use of benchmark data to improve quality practices

2. Amount of coordination between quality department and other departments

3. Amount of training in quality awareness provided to hourly employees

4. Amount of training in quality awareness provided to managers and supervisors

5. Amount of training in basic statistical techniques such as histograms and control charts

6. Amount of training in advanced statistical techniques (design of experiments and regression)

7. Availability of quality data (internal to the organization)

8. Collection of after sales quality data

9. Coordination among appropriate departments in the product/service development process

10. Degree to which company environment is conducive to employee well-being and growth

11. Degree to which divisional top management is evaluated based on quality performance

12. Degree to which employees throughout organization are evaluated on quality results

13. Degree to which quality is emphasized in design process vis-a-vis cost or schedule objectives

14. Development of procedures for monitoring key indicators of competitor performance

15. Development of procedures for monitoring key indicators of customer satisfaction

16. Development of procedures for monitoring key indicators of plant/company performance

17. Effectiveness of the quality department in improving quality

18. Emphasis on quality instead of price in the supplier selection process

19. Extent to which cross-functional teams are utilized

20. Extent to which employees can act on quality issues without approval from supervisors

21. Extent to which health and safety are emphasized by top management in our quality policy

22. Extent to which human resources management is affected by quality plans

23. Extent to which interfaces among different functional departments are formalized

24. Extent to which manufacturability is considered in the product design process

25. Extent to which manufacturing facility is used as showroom to demonstrate quality practices

26. Extent to which quality data is made visible (displayed at work-stations)

27. Extent to which top management emphasizes environmental protection in our quality policy

28. Extent to which top management clearly communicates quality goals

29. Extent to which top management emphasizes quality through a well-defined quality policy

30. Extent to which top management focuses on customer quality requirements to establish strategy

31. Extent to which top management provides resources to carry out quality improvement

32. Inclusion of customer attributes in product design through Quality Function Deployment (QFD)

33. Management's efforts to recognize and reward quality improvements

34. Quality department plays an active role in providing specific training such as SPC

35. Quality department's emphasis on inspection as the primary means of achieving high quality 
36. Responsiveness of employees in making suggestions regarding quality improvement

37. Timeliness of quality data (internal to the organization)

38. Visibility of the quality department

\section{Supply Base Management Practices}

On a scale of $1=$ strongly disagree to $7=$ strongly agree, indicate the most appropriate response regarding your firm's practice of the following areas of supply base management:

1. Commodity management teams set the levels of cost, quality and lead time for supplier performance

2. Local plant managers are given authority to execute purchase orders and daily supply flows

3. Low volume, low cost materials are handled by individual plant staff based on local needs

4. Our company has a quality-assurance (certified) program for our supplier's specific product

5. Our company has a quality-assurance program for our supplier's manufacturing process

6. Our company takes advantage of supplier-provided technical support and test capabilities

7. Our manufacturing personnel regularly visit our supplier's facility

8. Suppliers receive changes to our specifications AFTER we develop a new product design

9. We share a great deal of sensitive information with our suppliers

10. We undertake annual negotiations to establish the price for key-input items from our suppliers

\section{Customer Relations Practices}

On a scale of $1=$ poor to $7=$ excellent, rate your firm's ability to monitor and manage customer relationships in the following areas:

1. Determination of future customer expectations

2. Determination of key factors for building and maintaining customer relationships

3. Enhancement of customers' ability to seek assistance

4. Evaluation of formal and informal complaints

5. Follow-up with customers for quality/service feedback

6. Interaction with customers to set reliability, responsiveness, and other standards

7. Measurement and evaluation of customer satisfaction factors

\section{Performance}

On a scale of $1=$ below average to $7=$ above average, indicate the level of your firm's performance on each of the following dimensions compared to that of major industry competitors:

1. Market share

2. Return on total assets

3. Average annual market share growth (over the past three years)

4. Average annual sales growth (over the past three years)

5. Average annual growth in return on total assets (over the past three years)

6. Average production cost

7. Overall customer service levels

8. Overall product quality

9. Overall competitive position 